\title{
ROBERT D. SYMONS, NATURALIST, WRITER, ARTIST
}

In the words of Bob Symons, "The world is a beautiful place but by making it man-centred man himself has changed it to a place of destruction." Man has misunderstood that the position he enjoys, the position which has given him "dominion . . . over every living thing" entails a sense of responsibility. Perversely, man has misunderstood the injunction as a kind of carte blanche to dominate, even if his domination involves the breaking of natural cycles. Now he is discovering, with dismay, that, as a result of his blindness, his own destruction is possible, even imminent. He finds himself alternating between moods of nostalgia and despair.

When Mr. Symons talks, he exhibits both these moods which are common to modern man. He looks nostalgically at the past when people worked hard to maintain themselves, when they did not demand much in the way of physical ease, when they even had time to "stand and stare." He looks with despair at that large segment of the population still obsessed with the desire for material gain; at that group which lives in the cities but flocks in its spare time to the few remaining wilderness areas and proceeds, in the name of recreation, to pollute and destroy; and at that unhappy minority which, out of a frequently sincere revulsion against modern society, withdraws, yet is content to maintain a parasitical form of existence.

But Mr. Symons does not allow himself the indulgence of remaining in either of these negative moods for long. $\mathrm{He}$ is much too positive a personality for that. As he says himself, instead of wallowing in either nostalgia or despair we must stop and evaluate. If we do so, we shall, he believes, conclude that nature is always right and that all life (not just human life) is important. Central to grasping this concept is the need to restore to the imagination of man a sense of wonder. In no small way Bob Symons has, dur- ing his lifetime, contributed to the restoration of this sense by means 0 his conversation, his writing and his painting.

A conversation with Bob Symons is never dull. Because he is willing tc discuss any controversial topic, on may disagree with his viewpoints an disagree violently, but it is impossible to remain unstimulated. He has the ability to transmit the apprehension that to be alive is to be excited. For him there is so much to see, so much to ponder, so much to learn, so much to do, that to be bored or unaware is out of the question. The point here, of course, is that his sense of excitement grows out of the naturalist's knowledge of the complexity of the world. As : person who went sketching with him one day remarked, "He made me ses that a square yard of land could be the study of a lifetime."

Those who read Mr. Symons' book: are certain to be impressed by hi breadth of understanding and his sen sitivity. In The Broken Snare he em phasizes the instinctual quality of life (something which, incidentally, he believes modern man has denigrated) After the wolf escapes from the broker snare and the Man is "half-sorry, half glad," there is a section which subtly notes the link which connects the man and the animal:

"Within a week a chinook blew through a gash in the mountains. $\mathrm{He}$ [the wolf] was ready, rested and able to travel. He woke, stretched, and yawned, showing his strong young teeth below his drawn-back lip. He stood looking east to where three miles away Deep Springs Ranch lay shrouded in the grey of dawn.

It was seven o'clock, but the January sun would not show itself till after nine, although the Man was already astir. The wolf could see a tiny pin-point of light flickering between the house and the barn.

He howled once, long and quavering. It was his good-bye to Wild Horse Creek and the Cutbank.

The point of light stood still." 
Another kind of closeness between Man and creature (this time exhibiting the responsiveness of the essayist himself) occurs in Many Trails.

"I shall never forget one ride I had through a storm of snowflakes ["snow buntings" they are called by naturalists]. This was not the first time I had seen flocks of breathless magnitude but never before had I experienced the exhilaration of being lost in a blizzard of living, singing birds." Quietly the human being becomes a part of the "merry throng" as it expresses its "everlasting faith in the miracle of the seasons."

Many of the sections of Hours and the Birds show Symons' ability to combine accurate observation with imaginative speculation. Notice the approach he adopts in his treatment of the Snowy Owl, one of "the cats of the hird world":

"[The owl appears] like a snowleopard with his deep and fluffy feathers, more or less barred, or spotted with black, semi-concealed. His great round head and deeply "furred" legs and toes, no less than his calm quartering flight, make him an object of wonderment . . . at peace with the world.

Once, long ago, I saw a belated snowy owl perched on a cake of ice at Jackfish Lake. The spring break-up was in the last stages. The day was fine, the sun hot. From far out in the lake the hollow, musical voices of whistling swans rose and fell. Their flocks glistened white in the sunlight. Closer to shore, the snowy owl, evidently distressed, clung to his cool iceflow as the only friendly thing in this unfamiliar world. He shifted uneasily from time to time, turning his solemn head around as if he had no front or back, as the little waves rocked his craft. Then, taking flight, he winged towards the swans and circled above them several times. I think he mistook the flock for a bigger and better ice-cake, as he sought several times to settle but was sent back to his original perch by their clamour and threshing."

Mr. Symons' talent as a painter has een widely recognized. All three of is books include sketches and paintngs which are an integral part of the

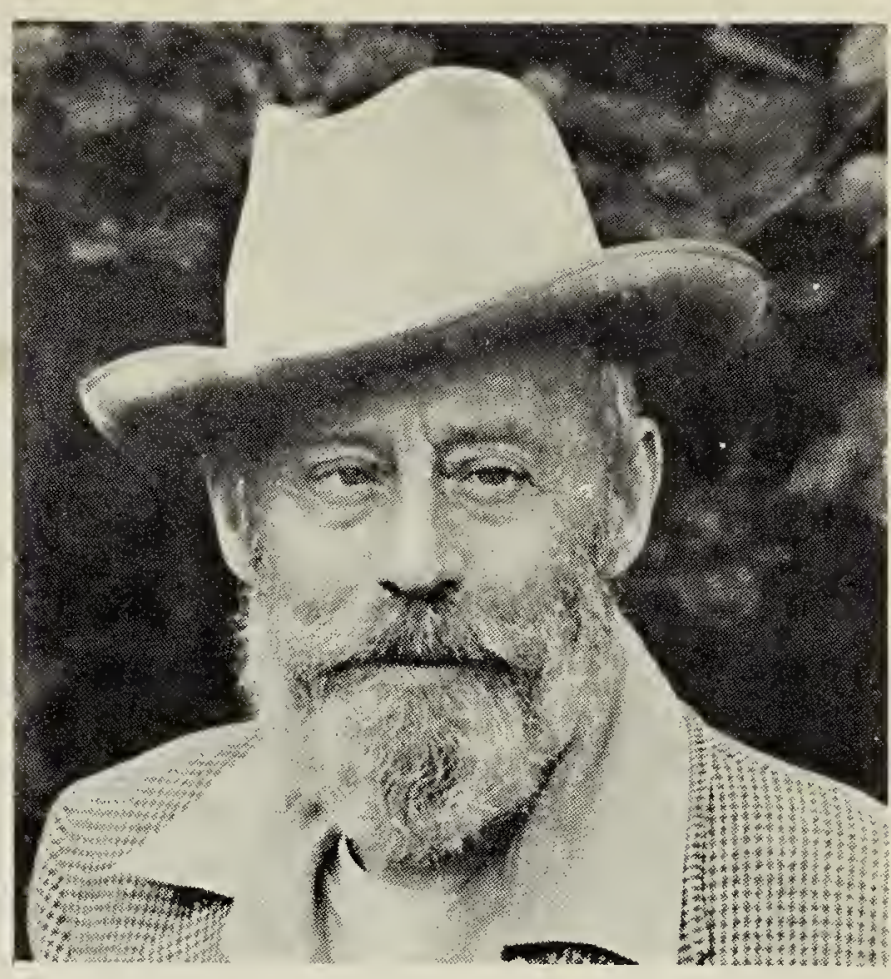

text. These, along with many other canvases which have found their way into a variety of private and public collections (and which include some of the diorama backgrounds at the Museum of Natural History), show him as an artist of great merit. His best work is the work of the skilled craftsman and the imaginative interpreter of the natural world.

This fall the University of Saskatchewan Regina Campus conferred an honorary doctor of laws degree on Robert David Symons. Margaret Belcher, in presenting him to the Chancellor of the University at the October convocation, said: "[Saskatchewan] is the country that he knows best, for he has followed its many trails from the High Plains of the Southwest where "the wind is part of all one loves", north to the "strong woods" of the old fur country and the lovely quiet of a forest ranger's station. It is also in Saskatchewan that Robert Symons has made his major contribution to the community and the arts, and the University of Saskatchewan now has the honour of recognizing that contribution."

A fitting tribute to the naturalistwriter-artist who in Hours and the Birds enunciates his philosophy thus: "Look for beauty and you will find it, remembering that the eye sees only as the heart directs."-Jeanie Wagner, Regina. 